Review

\title{
Emerging respiratory and novel coronavirus 2012 infections and mass gatherings
}

J.A. Al-Tawfiq, ${ }^{1}$ C.A.H. Smallwood, ${ }^{2}$ K.G. Arbuthnott, ${ }^{2}$ M.S.K. Malik, ${ }^{3}$ M. Barbeschi ${ }^{2}$ and Z.A. Memish ${ }^{4}$

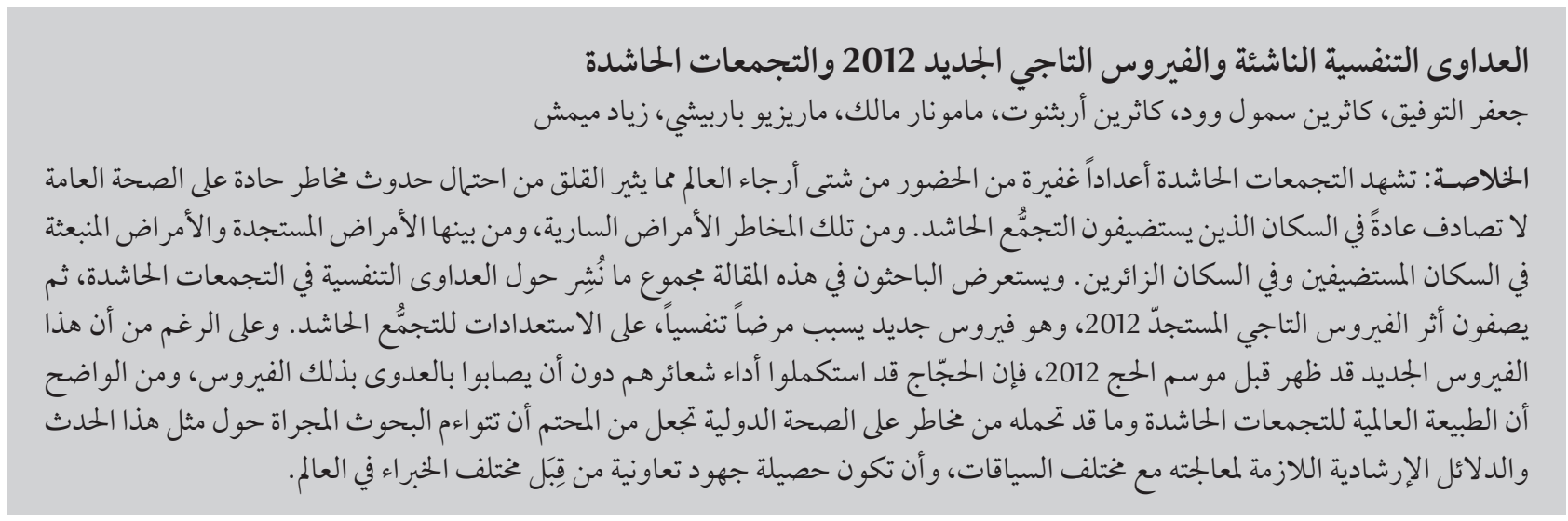

ABSTRACT Mass gatherings are attended by an increasingly global audience and thus raise the concern of possible acute public health risks not normally encountered by the host population. The potential acute risks to individual and population health include communicable diseases. The communicable disease risks include emerging and re-emerging diseases in host and visiting populations. In this review, we provide an overview of the literature on respiratory infections at mass gatherings, then describe the impact of novel coronavirus 2012 (nCoV), an emerging respiratory disease virus, on the preparations for mass gathering. Although, nCoV emerged prior to the 2012 Hajj pilgrimage season, Muslims completed their religious duty without acquiring infections by nCoV. Clearly, the global nature of mass gatherings and their potential risks to international health make it imperative that research on such events and guidelines produced for their management are relevant to diverse contexts and are a collaborative effort between global experts.

Infections respiratoires émergentes, nouveau coronavirus 2012 et rassemblements de masse

RÉSUMÉ Les rassemblements de masse réunissent un public de plus en plus mondial et soulèvent par conséquent des inquiétudes concernant des risques aigus potentiels pour la santé publique que la population hôte ne connaît pas habituellement. Les maladies transmissibles font partie des risques aigus potentiels pour la santé au niveau de l'individu et de la population. Les risques liés aux maladies transmissibles comprennent les affections émergentes ou réémergentes dans les populations hôtes et de passage. Dans la présente revue, nous proposons un aperçu de la littérature sur les infections respiratoires lors de rassemblements de masse, puis nous décrivons l'impact du nouveau coronavirus 2012, un virus respiratoire émergent, sur les préparatifs des rassemblements de masse. Toutefois, le nouveau coronavirus a sévi avant la saison du pèlerinage du Hadj de 2012 et les musulmans ont accompli leurs obligations religieuses sans contracter d'infection par ce virus. En clair, la nature mondiale des rassemblements de masse et les risques potentiels pour la santé internationale rendent impératif que la recherche sur de tels événements et les recommandations pour leur prise en charge soient adaptées aux divers contextes et soient le résultat d'une concertation d'experts mondiaux.

${ }^{7}$ Saudi Aramco Medical Services Organization, Dhahran, Saudi Arabia.

${ }^{2}$ Alert and Response Operations, Global Capacities, Alert and Response, World Health Organization, Geneva, Switzerland.

${ }^{3}$ Pandemic and Epidemic Disease, Regional Office for the Eastern Mediterranean, World Health Organization, Cairo, Egypt.

${ }^{4}$ Ministry of Health, Riyadh, Saudi Arabia; College of Medicine, Al Faisal University, Riyadh, Saudi Arabia (Correspondence to Z.A. Memish: zmemish@yahoo.com). 


\section{Risks of infectious disease at mass gatherings}

With the advent of more widely available air travel, mass gatherings are attended by an increasingly global audience [1]. This, combined with potentially increased crowd numbers, raises the concern of possible acute public health risks. Some risks are common to most mass gatherings, but others are specific to a given gathering or crowd. The potential acute risks to individual and population health range from noncommunicable disease concerns, such as crush injuries [2], to infectious agents [3]. Minimizing the risk of communicable diseases at mass gathering is therefore an important part of global health security. A mass gathering is defined by the World Health Organization (WHO) as an occasion that "attracts a sufficient number of people to strain the planning and response resources of a community, state or nation" [4]. It follows that mass gathering can be planned or spontaneous, and can be diverse in purpose, from music festivals and protests to large-scale religious events. At mass gatherings, communicable disease risks include emerging and re-emerging diseases in host and visiting populations. The possible impact of such outbreaks during mass gathering is serious, potentially resulting in the dissemination of the disease to different countries upon the return of attendees to their countries of origin [5].

Concerns about communicable disease spread at a given mass gathering are focused on the problems of crowding, lack of sanitation and temporary food stalls, travel and movement of population groups. Communicable disease threats may arise from pathogens with different modes of transmission, such as faeco-oral, vector-borne, zoonotic, sexually transmitted and bloodborne pathogens and these risks have been reviewed elsewhere [3]. One concern among host countries is the spread of respiratory disease. The risk of respiratory pathogen spread may, among other factors, depend on crowd density and length of stay, in addition to hygiene facilities and the capacity for diagnostics and appropriate isolation. The type of respiratory disease risk will be influenced by the endemic disease patterns in the host and visiting nations, and by seasonality or climate [6]. The ability to detect and diagnose specific respiratory pathogens at mass gatherings depends on the participants seeking health care, ready access to health-care treatment facilities, and the availability of rapid laboratory diagnostics to the health-care clinicians. The probability of a specific pathogen causing an epidemic among the participants at mass gathering depends on the population immunity to the pathogen, the incubation period of a particular infectious agent before symptoms of disease emerge and the length of time the mass gathering participants are in close contact with each other. If an outbreak were to occur at a mass gathering, there are potential implications for international public health and for the revised International Health Regulations [7]. Under Annex 2, the revised Regulations outline criteria for the assessment and notification of potential public health events of international concern. These criteria may be influenced by the occurrence of a mass gathering.

To better prepare for the increased communicable disease threats, public health preparations for all mass gatherings should include a specific focus on enhanced disease surveillance and risk assessment. This extends from the local level of the mass gathering, to the national and international levels. For example, additional diseases, which are non-endemic in the host country but endemic in the visitors' countries, may be included on "priority condition" lists for reporting. Furthermore, surveillance sites may be implemented at additional geographical locations, for example at ports of entry or around the mass gathering location. Laboratory capacity may also be strengthened to accommodate surge capacity and for diagnosis of non-endemic diseases.

A number of large mass gatherings took place in 2012, including the Olympic Games in London, annual events such as the Hajj pilgrimage in Mecca and many spontaneous political rallies in countries of the Eastern Mediterranean Region. The discovery of the novel coronavirus ( $\mathrm{nCoV}$ ), with evidence of human cases appearing approximately 1 month before Hajj 2012, necessitated an iterative approach to risk assessment and management before, during and after the event.

\section{Objectives of the review}

This review, based on information up to March 2013, presents some of the issues surrounding emerging respiratory infections at mass gatherings, with a particular focus on $\mathrm{nCoV}$ and the Hajj. An overview of the literature on respiratory infections at mass gatherings is presented, followed by a narrative describing the impact of $\mathrm{nCoV}$, an emerging respiratory disease, on the preparations before, during and after Hajj 2012.

\section{Viral respiratory infections at Hajj and other mass gatherings}

The Hajj takes place during the 12th month of the Islamic calendar, and according to Islam, every able Muslim must undertake the pilgrimage to Mecca once in their lifetime. Just as for any international mass gathering, the potential for large epidemics during Hajj has been, and will continue, to present a considerable challenge to attending pilgrims and the local communities. The risks, comprehensively described in other publications, arise from the attendance of close to 4 million 
pilgrims from more than 180 countries [8]. The number of foreign pilgrims attending Hajj is increasing every year (Figure 1). This change in population attendance may affect the disease risks present at Hajj.

It has been argued that the potential for respiratory tract infections during mass gatherings is related to the large number of people coming from different parts of the world. Intense crowding of people in limited spaces facilitates the transmission of disease, especially that of airborne infections [8]. The congested conditions of the Hajj and the crowded nature of the accommodation contribute to the transmission of communicable diseases at the pilgrimage [9].

Influenza outbreaks during mass gathering have been described previously [10-13]. A modelling study by Shi et al. has suggested that mass gathering could be associated with a $10 \%$ increase in the attack rate of influenza if they occur within 10 days before an influenza pandemic [14]. Studies on the occurrence of influenza during mass gatherings were also undertaken during the 2002 Winter Olympics in Salt Lake City in the United States and during World Youth Day 2008 in Sydney, Australia [12,13]. Among the total 188 patients tested at the World Youth Day 2008, influenza A and $B$ were diagnosed in 19\% [13]. During World Youth Day 2008, a number of influenza strains were identified and these included oseltamivir-resistant and -sensitive influenza $\mathrm{A}(\mathrm{H} 1 \mathrm{~N} 1)$ viruses, influenza $A(H 3 N 2)$ viruses and influenza $B$ lineages (B/Florida/4/2006-like virus and $\mathrm{B} /$ Malaysia/2506/2004-like virus) [13]. The presence of multiple viruses among those attending mass gathering may increase the opportunity for the emergence of novel reassortment viruses [13].

In a third study describing the occurrence of influenza during a rock festival in Hungary, among the total attendants of 390000 young people, 14 individuals were examined at St Margareta hospital and $8(57.1 \%)$ tested positive for

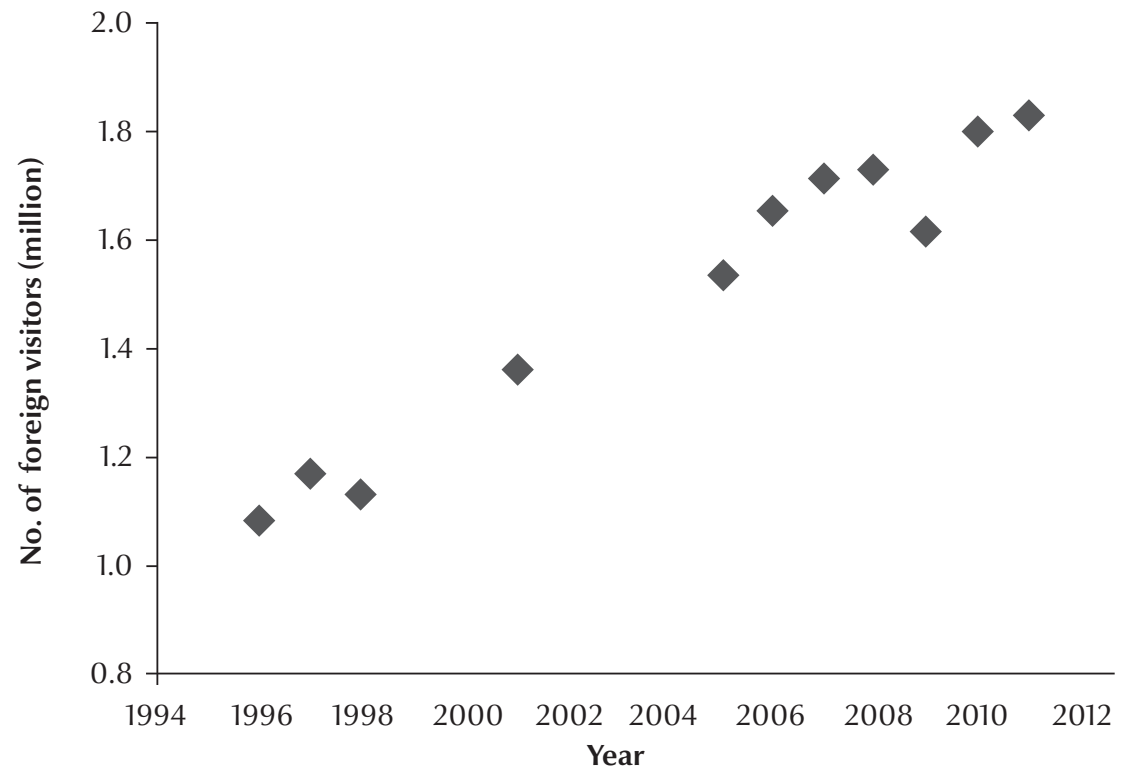

Figure 1 Annual counts of foreign visitors to the Hajj, 1996 to 2011 (Source: Ministry of Health, Saudi Arabia)

influenza $\mathrm{A}(\mathrm{H} 1 \mathrm{N1})$ pdm09 by real-time polymerase chain reaction (PCR) assay [15]. The incidence was 3.7 times the overall European value, and may have been higher since attendees may not have sought medical treatment [15]. During the inauguration of the Asian Youth Games in Singapore in 2009, 66 suspected cases of influenza $\mathrm{H} 1 \mathrm{~N} 1$ virus were screened; 6 were confirmed for influenza A(H1N1)pdm09 and were admitted to hospital for isolation and treatment [16]. In Serbia, a few influenza A(H1N1) cases were identified among participants attending 2 mass gatherings and it was not possible to assess their impact on local populations [17]. Transmission of influenza $\mathrm{A}(\mathrm{H} 1 \mathrm{~N} 1)$ was inevitable, but preparations were put in place to mitigate the situation, including detection, isolation options and treatment of cases [17].

Further studies on respiratory viruses at mass gatherings have been related to the Hajj $[10,11]$. A range of respiratory viruses have been described among pilgrims attending the annual Muslim pilgrimages in Saudi Arabia [18-25]. In these studies, the prevalence of parainfluenza virus was $1 \%-7.4 \%[19,23]$, adenovirus was $5.4 \%$ [23], influenza $A(\mathrm{H} 1 \mathrm{~N} 1)$ was $2.5 \%$ $21.8 \%$ [18], influenza B was $0.8 \%-2.6 \%$
$[10,11]$ and influenza was $0.2 \%-37.4 \%$ $[10,11,19,21-23]$. The difference in the detection rates in these studies were related to the study design and the included population. For example, using a PCR assay, influenza was detected in 10\%-12\% of symptomatic pilgrims $[11,22]$ versus $1 \%$ among a sample of Egyptian returning pilgrims without the mention of any specific symptoms [21]. In another study of 305 pilgrims arriving at Shiraz airport, Islamic Republic of Iran, pandemic 2009 influenza $\mathrm{A}(\mathrm{H} 1 \mathrm{~N} 1)$ virus was detected in $1.6 \%$ pilgrims and other influenza $\mathrm{A}$ viruses were detected in $2.6 \%$ [26]. A recent study reviewed respiratory tract infections during the annual Hajj with comments on the potential risks [27].

\section{Emergence of novel coronavirus infections prior to Hajj 2012}

The first recorded infections with the $2012 \mathrm{nCoV}$ occurred only a few months before the Hajj season in 2012 and were only reported publicly a few weeks ahead of the pilgrimage [28]. The first reported infection with $\mathrm{nCoV}$ 
was identified in the Saudi Arabian port city of Jeddah, in a Saudi Arabian male who died in June 2012 [29,30]. A second case was reported in a Qatari male with a history of travel to Saudi Arabia in late September 2012 [31,32]. The emergence of this virus in humans came at a time when Muslims from around the world were preparing to converge on Saudi Arabia for the Hajj pilgrimage given that the first reported case occurred in Jeddah, where Hajj pilgrims assemble, risks to Hajj had to be considered by Saudi authorities, by $\mathrm{WHO}$, and by the national authorities of countries of the participating pilgrims [29]. Figure 2 illustrates the timing of initial infections with $\mathrm{nCoV}$ and Hajj 2012. The first 2 reported cases of $n \mathrm{CoV}$ sparked significant media interest in the implications of a new virus that was of the same family as the severe acute respiratory syndrome (SARS) coronavirus. Studies of the 2003 SARS outbreak found that the SARS virus was not easily transmitted between humans and required close contact or facilitated transmission by aerosol production
[33]. As attention turned to the possible implications of $\mathrm{nCoV}$ infections for the Hajj, the available information about the virus was extremely limited. Genetically, it closely resembled other coronaviruses associated with bats, but the reservoir, the mechanism of acquisition and its spread were not known. Based on the initial information provided by the first reported cases of $\mathrm{nCoV}$, no human-to-human transmission had occurred [32] and, as such, there were no travel restrictions to areas with reported cases.

\section{Risks of novel coronavirus to public health at Hajj 2012}

\section{Preparations leading to Hajj 2012}

As described above, evidence exists for sustained communicable disease transmission at mass gathering such as Hajj. The discovery of $\mathrm{nCoV}$ infections in the location of the Haij meant that the late stages of planning for Hajj 2012 had to account for this new disease. A unique component of Saudi Arabia's approach to managing public health risks to pilgrims is the preparation and revision on an annual basis of the recommendations and health requirements for the period of the pilgrimage. Once developed by the Ministry of Health of Saudi Arabia, these requirements are shared through national and international platforms, including WHO's Weekly Epidemiological Record. Since 2009, the Weekly Epidemiological Record has communicated different types of information to the international community. This ranges from general advice to target populations, to requirements at points/ports of entry, to vaccination obligations for all pilgrims. For instance, during pandemic influenza A(H1N1) 2009, Saudi Arabia recommended that immunocompromised, extremely overweight or pregnant individuals defer travel plans to another year [34]. In 2000 and 2001, coinciding with Hajj, an international outbreak of disease was caused by a rare strain of Neisseria meningitidis, serogroup W135. This prompted Saudi

30

November

Jordan

reports 2

retrospec-

tive cases

from a

hospital

cluster presents with

symptoms and dies
Qatari case

onset of

symptoms in Qatar
Hajj 2012

from 10-30

October

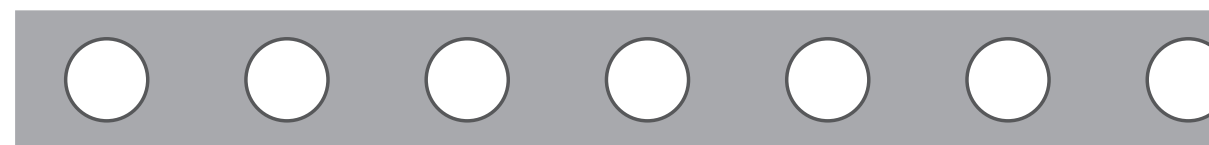

Mid July

Erasmus

Medical

Centre tests

samples and

obtains virus

culture

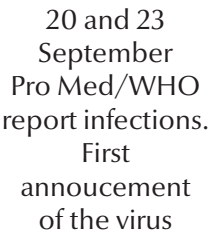

23
November
Saudi
Arabia
reports
family
cluster of
nCoV
cases.
Qatar
reports
additional
case.

11

February

2013

onwards

Further

cases of

$\mathrm{nCoV}$

detected 
Arabian health authorities to introduce a mandatory vaccination requirement of quadrivalent ACWY meningitis vaccine for Hajj 2002 [35].

Requirements and recommendations for Hajj seasons are also revised on an ad hoc basis as and when acute public health events are judged by Saudi Arabian authorities to present a risk to Hajj attendees. In July 2012, preliminary recommendations and requirements for Hajj were issued and published in the Weekly Epidemiological Record [36]. Viral respiratory infections were addressed within specific recommendations for seasonal influenza vaccination for national and international pilgrims. In addition, the 2012 recommendations made specific reference to the importance of routine vaccinations, especially for measles and rubella due to the recent resurgence of these diseases around the globe [36]. Initial information for Hajj 2012 did not include specific recommendations to infections due to $\mathrm{nCoV}$ as in July 2012 the disease had yet to emerge as a public health risk.

In October 2012, Saudi Arabia updated information on health hazards and recommendations for Hajj 2012 in an article published in Eurosurveillance [28]. These revisions provided further requirements for Hajj pilgrims coming from Uganda, the Democratic Republic of the Congo and Sierra Leone on the basis of ongoing outbreaks of communicable disease at that time. The paper also recommended specific measures to reduce the risk of transmission of viral respiratory infections, including those associated with $\mathrm{nCoV}$ but it did not issue any travel restrictions with respect to $\mathrm{nCoV}$ infections. Saudi Arabia reminded pilgrims to "practice proper hand hygiene, protective behaviours and cough etiquette to further decrease the occurrence of respiratory diseases". Other countries also issued $\mathrm{nCoV}$ guidance to their nationals visiting Saudi Arabia for the Hajj, such as Britain [37] and the United States [38]. Some countries advised their nationals to seek medical attention if, on return from Hajj, they developed acute respiratory symptoms.

\section{Public health measures adopted during the Hajj pilgrimage}

Public health efforts to maintain a high level of excellence during the Hajj are coordinated by 24 supervisory committees [39]. To enhance the effectiveness of activities, an electronic surveillance system is used by public health teams and teams at points of entry. This enhanced surveillance targets influenza, influenza-like illness, meningococcal disease, food poisoning, viral haemorrhagic fevers, yellow fever, cholera, polio and plague [39]. In line with Saudi Arabia's policy of providing free access to health care during the Hajj, there were 25 hospitals offering 4964 beds including 547 critical care beds [28]. Health care was also provided through 141 medical centres in the Hajj area [28].

The Saudi Arabian Ministry of Health case definition for $\mathrm{nCoV}$ was published in Eurosurveillance [28]. A suspected case was defined as a person requiring hospitalization with community-acquired acute respiratory syndrome with symptoms of: fever $(\geq$ $38^{\circ} \mathrm{C}$ ) and cough; and confirmed lower airways involvement (clinical and radiological evidence of pneumonia) not explained by any other infection or other etiology. A confirmed case was defined as a person with laboratoryconfirmed infection with $\mathrm{nCoV}$ [28]. The current $\mathrm{WHO}$ definitions for case finding include the definition for a confirmed case (a person with laboratory confirmation of infection with the $\mathrm{n}(\mathrm{CoV})$ and a probable case [40]. A probable case is defined as a person with an acute respiratory infection with clinical, radiological or histopathological evidence of pulmonary parenchymal disease (e.g. pneumonia or acute respiratory distress syndrome); and no possibility of laboratory confirmation for $\mathrm{nCoV}$ either because the patient or samples are not available for testing; and close contact with a laboratoryconfirmed case [40].

The lack of information or evidence on the severity and transmissibility of this novel virus in mass gathering situations raised concerns for the Hajj. As for other viruses in the coronavirus family, the infection was thought to spread by aerosol droplets [41]. The pattern of transmission of $\mathrm{nCoV}$ in overcrowded and congested settings, such as those of Hajj, posed a big "unknown" to the international community as well as to the Saudi national health authorities.

The risk of international $\mathrm{nCoV}$ spread as a result of imported cases from returnee pilgrims was also unknown. Examples of this had been previous documented, as seen in the 2000 and 2001 outbreaks of meningococcal meningitis W135 [9,42]. This prompted the Saudi Arabian national health authorities to consult with international health partners, including $\mathrm{WHO}$, to rapidly develop and put into practice an appropriate strategy for detection of suspect $\mathrm{nCoV}$ cases among pilgrims.

The annual Hajj took place from 10-31 October 2012 and approximately 4 million pilgrims took part. Pilgrims came from 187 countries and visited the main religious sites of Saudi Arabia in Mecca and Medina. The Hajj of 2012 was declared by Saudi Arabia as free from any public health event and not a single case of $\mathrm{nCoV}$ infection was detected through the national surveillance system. Over 300 sick pilgrims were tested for $\mathrm{nCoV}$ infections and all were found to be negative [43].

Screening of returnee pilgrims was also carried out in Europe and elsewhere. No imported cases of $\mathrm{nCoV}$ infections were reported to WHO from these countries. In a cohort of 154 French pilgrims returning from Hajj $2012,83.4 \%$ had respiratory symptoms and $41 \%$ had influenza-like illness [44]. All the pilgrims screened tested negative for $\mathrm{nCoV}$ by real-time PCR assays [44]. 


\section{Impact of further cases on future mass gatherings}

At the time of writing (March 2013), WHO had been informed of a total of 15 confirmed cases of human infection with $\mathrm{nCoV}$, including 9 deaths [45]. Eight of these cases including 6 deaths were reported from Saudi Arabia. The majority of cases presented with severe illness. Limited, but not sustained, human-to-human transmission has also been reported in cases in the United Kingdom [46] and in Jordan. The cases in Jordan were detected retrospectively [47]. A Saudi investigation into a family cluster of 3 confirmed and 1 probable case - conducted after the Hajj in 2012 - remained inconclusive but the dates of onset of symptoms of this family cluster of cases appeared to be consistent with human-to-human transmission [46]. Given new information on the transmission and the reported incidence of the virus following the Haij in 2012, the epidemiological potential for an outbreak of $\mathrm{nCoV}$ infections during this year's Hajj in 2013 may be more likely. The occurrence of $\mathrm{nCoV}$ infections and the possible evolving patterns of transmission should be closely monitored and assessed by the international community and Saudi authorities ahead of this year's Haij in October 2013.

Another factor related to $\mathrm{nCoV}$ that may impact on the Hajj in 2013 is the epidemiology of this emerging disease. If populations susceptible to $\mathrm{nCoV}$ are found to be demographically similar to those attending Hajj, the risks posed to the Hajj may be increased.

Global public health vigilance will be important to see how the public health risk associated with this novel virus unfolds. International collaborations will be crucial to protect global health as Hajj and mass gathering in the face of a potentially deadly virus that may seriously affect global health security.

\section{Importance of international collaborations}

As part of this international collaboration to prevent any global spread of $\mathrm{nCoV}$ infection through spread of Hajj-related infections, teams of disease experts converged on Saudi Arabia immediately before the Hajj. These included epidemiologists from WHO and the United States Centers for Disease Control in Atlanta, virologists from the Center for Infection and Immunity at Columbia University in New York and experts in the control of zoonotic diseases from EcoHealth, a New York city-based international organization for ecology and health. These specialists were invited by the Saudi Arabian government. The Saudi Arabian National Committee for Infectious Diseases worked with WHO to rapidly develop a case definition and protocol for detecting and testing pilgrims who developed a respiratory infection [40]. An investigation of potential environmental and animal sources of the $\mathrm{nCoV}$ was carried out by the team from Columbia University.

In addition to international collaboration with regards to $\mathrm{nCoV}$, the global nature of mass gathering and potential risks to international health and security, make it imperative that the research and guidelines produced are relevant to diverse contexts and are a collaborative effort between global experts and centres. This is important, not only as emergence of new pathogens is a continued threat with implications for transmission and international spread at mass gathering, but to foster a culture of sharing of knowledge and expertise more generally across the field. This should extend to areas as diverse as communicable and noncommunicable diseases and to ensure a legacy of practical knowledge transfer and sharing of lessons learned.

There are many centres and individuals with academic and practical expertise in this mass gathering and a current commitment exists to bring such organizations and individuals together through formal and informal networks and collaborations. Examples of these networks include the WHO virtual interactive advisory group on mass gatherings, the newly formed Global Mass Gatherings Network and the developing network of WHO collaborating centres on mass gatherings.

\section{References}

1. Al Rabeeah AA et al. Mass gatherings medicine and global health security. Lancet, 2012, 380:3-4.

2. Steffen $\mathrm{R}$ et al. Non-communicable health risks during mass gatherings. Lancet Infectious Diseases, 2012, 12:142-149.

3. Abubakar I et al. Global perspectives for prevention of infectious diseases associated with mass gatherings. Lancet Infectious Diseases, 2012, 12:66-74.

4. Communicable disease alert and response for mass gatherings. Technical workshop, Geneva, Switzerland, 29-30 April 2008. Geneva, World Health Organization, 2008 (WHO/HSE/ $\mathrm{EPR} / 2008.8$ )
5. Memish ZA, Venkatesh S, Ahmed QA. Travel epidemiology: the Saudi perspective. International Journal of Antimicrobial Agents, 2003, 21:96-101.

6. Altizer $\mathrm{S}$ et al. Seasonality and the dynamics of infectious diseases. Ecology Letters, 2006, 9:467-484.

7. International health regulations (2005), 2nd ed. Geneva, World Health Organization, 2005.

8. Al-Tawfiq JA, Memish ZA. Mass gatherings and infectious diseases: prevention, detection, and control. Infectious Disease Clinics of North America, 2012, 26:725-737. 
9. Ahmed QA, Arabi YM, Memish ZA. Health risks at the Hajj. Lancet, 2006, 367:1008-1015.

10. Balkhy HH et al. Influenza a common viral infection among Hajj pilgrims: time for routine surveillance and vaccination. Journal of Travel Medicine, 2004, 11:82-86.

11. El Bashir H et al. Influenza among UK pilgrims to hajj, 2003. Emerging Infectious Diseases, 2004, 10:1882-1883.

12. Gundlapalli AV et al. Influenza, Winter Olympiad, 2002 Emerging Infectious Diseases, 2006, 12:144-146.

13. Blyth CC et al.; World Youth Day 2008 Influenza Study Group. Influenza outbreaks during World Youth Day 2008 mass gathering. Emerging Infectious Diseases, 2010, 16:809-815.

14. Shi P et al. The impact of mass gatherings and holiday traveling on the course of an influenza pandemic: a computational model. BMC Public Health, 2010, 10:778.

15. Botelho-Nevers $E$ et al. Travel-related influenza A/H1N1 infection at a rock festival in Hungary: one virus may hide another one. Journal of Travel Medicine, 2010, 17:197-198.

16. Van Hal SJ et al. Influenza outbreak during Sydney World Youth Day 2008: the utility of laboratory testing and case definitions on mass gathering outbreak containment. PLOS ONE, 2009, 4:e6620.

17. Loncarevic $G$ et al. Public health preparedness for two mass gathering events in the context of pandemic influenza (H1N1) 2009-Serbia, July 2009. Eurosurveillance, 2009, 14:pii 19296.

18. Mandourah $\mathrm{Y}$ et al. Clinical and temporal patterns of severe pneumonia causing critical illness during Hajj. BMC Infectious Diseases, 2012, 12:117

19. Alborzi A et al. Viral etiology of acute respiratory infections among Iranian Hajj pilgrims, 2006. Journal of Travel Medicine, 2009, 16(4):239-242.

20. Alherabi AZ. Impact of pH1N1 influenza A infections on the otolaryngology, head and neck clinic during Hajj, 2009. Saudi Medical Journal, 2011, 32:933-938.

21. Kandeel A et al. Pandemic (H1N1) 2009 and Hajj pilgrims who received predeparture vaccination, Egypt. Emerging Infectious Diseases, 2011, 17:1266-1268.

22. Rashid $\mathrm{H}$ et al. Influenza and respiratory syncytial virus infections in British Hajj pilgrims. Emerging Health Threats, 2008, 1:e2.

23. Rashid $\mathrm{H}$ et al. Viral respiratory infections at the Hajj: comparison between UK and Saudi pilgrims. Clinical Microbiology and Infection, 2008, 14:569-574.

24. El-Sheikh SM et al. Bacteria and viruses that cause respiratory tract infections during the pilgrimage (Haj) season in Makkah, Saudi Arabia. Tropical Medicine and International Health, 1998 3:205-209.

25. Memish ZA et al. Detection of respiratory viruses among pilgrims in Saudi Arabia during the time of a declared influenza A(H1N1) pandemic. Journal of Travel Medicine, 2012, 19:15-21.

26. Lim HC et al. The influenza A (H1N1-2009) experience at the inaugural Asian Youth Games Singapore 2009: mass gathering during a developing pandemic. British Journal of Sports Medicine, 2010, 44:528-532.

27. Al-Tawfiq JA, Zumla A, Memish ZA. Respiratory tract infections during the annual Hajj: potential risks and mitigation strategies. Current Opinion in Pulmonary Medicine, 2013, 19:192-197.

28. Al-Tawfiq JA, Memish ZA. The Hajj: updated health hazards and current recommendations for 2012. Eurosurveillance, 2012, 17:pii 20295.

29. Novel coronavirus-Saudi Arabia: human isolate. ProMed, 2012, archive number 1302733:20.
30. Corman VM et al. Detection of a novel human coronavirus by real-time reverse-transcription polymerase chain reaction. Eurosurveillance, 2012, 17:pii 20285.

31. Novel coronavirus infection-update. 25 September 2012. World Health Organization [online] (http://www.who.int/csr/ don/2012_09_25/en/index.html, accessed 7 MAY 2013).

32. Bermingham A et al. Severe respiratory illness caused by a novel coronavirus, in a patient transferred to the United Kingdom from the Middle East, September 2012. Eurosurveillance, 2012, 17:pii 20290.

33. Skowronski DM et al. Severe acute respiratory syndrome (SARS): a year in review. Annual Review of Medicine, 2005, $56: 357-381$

34. Health conditions for travellers to Saudi Arabia for the pilgrimage to Mecca (Hajj). Weekly Epidemiological Record, 2009, 84:477-480.

35. Al-Tawfiq JA, Clark TA, Memish ZA. Meningococcal disease: the organism, clinical presentation, and worldwide epidemiology. Journal of Travel Medicine, 2010, 17(Suppl.):3-8.

36. Health conditions for travellers to Saudi Arabia for the pilgrimage to Mecca (Hajj). Weekly Epidemiological Record, 2012, 87:277-280.

37. Novel coronavirus-advice for travellers, including Hajj pilgrims. Clinical updates, 15 October 2012. National Travel Health Network and Centre [online] (http://www.nathnac.org/pro/ clinical_updates/coronavirus_151012.htm, accessed 7 May 2013).

38. Severe respiratory illness associated with a novel coronavirusSaudi Arabia and Qatar, 2012. MMWR Morbidity and Mortality Weekly Report, 2012, 61(40):820-820.

39. Memish ZA. The Hajj: communicable and non-communicable health hazards and current guidance for pilgrims. Eurosurveillance, 2010, 15:pi 19671.

40. Revised interim case definition for reporting to $W H O$-novel coronavirus. 19 February 2013. World Health Organization [online] (http://www.who.int/csr/disease/coronavirus_infections/ case_definition/en/index.html, accessed 7 May 2013).

41. Malik $\mathrm{M}$ et al. Emergence of novel human coronavirus: public health implications in the Eastern Mediterranean Region. Eastern Mediterranean Health Journal, 2012, 18:1084-1085.

42. Memish ZA, Venkatesh S, Ahmed QA. Travel epidemiology: the Saudi perspective. International Journal of Antimicrobial Agents, 2003, 21:96-101.

43. Novel coronavirus-Eastern Mediterranean (03): Saudi comment, 12 February 2013. ProMed, 2013, archive number 20130212.1540011.

44. Gautret $\mathrm{P}$ et al. Lack of nasal carriage of novel corona virus (HCoV-EMC) in French Hajj pilgrims returning from the Hajj 2012, despite a high rate of respiratory symptoms. Clinical Microbiology and Infection, 2013, Feb 11 (doi: 10.1111/14690691.12174).

45. Novel coronavirus infection in the United Kingdom. 23 September 2012, update 12 March 2013. World Health Organization [online] (http://www.who.int/csr/don/2013_03_12/en/index. htmlhttp://www.who.int/csr/don/2012_09_23/en/index. html, accessed 7 May 2013).

46. Novel coronavirus infection-update. 16 February 2013. World Health Organization [online] (http://www.who.int/csr/ don/2013_02_16/en/index.html, accessed 7 May 2013).

47. Novel coronavirus infection-update. 30 November 2012. World Health Organization [online] http://www.who.int/csr/ don/2012_11_30/en/index.html, accessed 7 May 2013). 